\title{
KEMANDIRIAN PETERNAK SAPI PERAH ANGGOTA KOPERASI SUSU WARGA MULYA SLEMAN, DAERAH ISTIMEWA YOGYAKARTA
}

\section{THE SELF-RELIANCE OF WARGA MULYA DAIRY COOPERATIVE MEMBERS, SLEMAN, DAERAH ISTIMEWA YOGYAKARTA PROVINCE}

\author{
${ }^{*}$ Endang Sulastri, F. Trisakti Haryadi, Budi Guntoro, Siti Andarwati, \\ Ahmad Romadhoni Surya Putra \\ Fakultas Peternakan, Universitas Gadjah Mada, Sleman, Yogyakarta
}

Submitted: 23-09-2021; Revised: 20-12-2021; Accepted:29-12-2021

\begin{abstract}
The self reliance becomes a critical issue for community farming in Indonesia. This is the case in the process of increasing the production of quality milk and the development of dairy farmers in Indonesia. Domestic milk production in Indonesia still does not meet the amount of market demand until, this results in the dependence on milk imports is still quite high. Therefore, the demands of the Milk Processing Industry (IPS) require farmers to increase production and the quality of the milk produced becomes an important theme in the discussion and analysis of this research. The focus this study on the issue of farmer's self reliance that is analyzed based on indicators of decision making, creativity and problem-solving solutions. In particular, this study examines the level of self reliance of farmers who were the members of dairy cooperative and to analyze the factors influencing the farmers' self reliance. The survey was conducted on 52 farmers who were the members of Warga Mulya Dairy Cooperative. The self reliance of farmers was analyzed with the score, while the factors of age, education, productive dairy cows holding, and experience were analyzed by a regression analysis. This study concludes that farmers who are members of the Warga Mulya Dairy Cooperative majority have self reliance in the moderate category. Based on these results, it can be said that farmers have sufficient self reliance in running their dairy businesses. Nonetheless, farmers still have major obstacles related to decision making on the determination of the selling price of milk. This is because farmers do not have the independence to determine the selling price of milk.
\end{abstract}

Keywords: Farmers;Cooperatives;Self Reliance;Productive dairy cows holding.

\begin{abstract}
ABSTRAK
Kemandirian menjadi isu penting bagi komunitas peternak di Indonesia. Dalam hal ini akan dibahas dalam kasus proses peningkatan produksi susu berkualitas dan pengembangan peternakan sapi perah di Indonesia. Produksi susu dalam negeri di Indonesia masih belum memenuhi jumlah permintaan pasar hingga, hal ini mengakibatkan ketergantungan atas impor susu masih cukup tinggi. Oleh karena itu, tuntutan Industri Pengolahan Susu (IPS) mengharuskan peternak untuk meningkatkan produksi
\end{abstract}

*Corresponding author: endangs@ugm.ac.id

Copyright@ 2021 THE AUTHOR (S). This article is distributed under a Creative Commons Attribution-Share Alike 4.0 International license. Jurnal Kawistara is published by the Graduate School of Universitas Gadjah Mada. 
dan juga kualitas susu yang dihasilkan menjadi tema penting dalam pembahasan dan analisis penelitian ini. Fokus perhatian dalam penelitian menekankan pada isu kemandirian peternak. Penelitian ini akan menganalisis berdasarkan indikator pengambilan keputusan, kreativitas dan solusi pemecahan masalah. Secara khusus, penelitian ini menganalisis tingkat kemandirian peternak anggota koperasi dan mengetahui faktor-faktor yang kemandirian peternak. Penelitian menggunakan metode survey dengan jumlah sampel 52 peternak anggota Koperasi Susu Warga Mulya. Kemandirian peternak dianalisis dengan menggunakan skor, sementara untuk mengetahui pengaruh umur, pendidikan, kepemilikan betina produktif dan pengalaman beternak terhadap kemandirian peternak sapi perah dilakukan uji regresi. Studi ini menyimpulkan bahwa peternak yang tergabung dalam Koperasi Susu Warga Mulya mayoritas memiliki kemandirian dalam kategori sedang. Berdasarkan hasil tersebut, dapat dijelaskan bahwa peternak memiliki kemandirian yang cukup dalam menjalankan usahanya. Meskipun demikian, peternak masih memiliki kendala besar terkait pengambilan keputusan penetapan harga jual susu. Hal ini dikarenakan peternak tidak memiliki kemandirian untuk menentukan harga jual susu.

Kata Kunci: Peternak;Koperasi;Kemandirian;Ek onomi;Kepemilikan betina produktif.

\section{PENGANTAR}

Pengembangan peternakan sapi perah merupakan usaha yang mempunyai prospek strategis dalam pembangunan peternakan di Indonesia, dan akan berhasil jika melibatkan seluruh subsistem dari penyediaan sarana produksi sampai pada pemasaran produk peternakan (Soetriono et al., 2020; Nurtini \& Muzayyanah, 2014). Pengembangan sektor peternakan khususnya usaha ternak sapi perah perlu dilakukan karena kemampuan pasokan susu peternak lokal saat ini baru mencapai 25 persen sampai 30 persen dari kebutuhan susu nasional. Maka hingga saat ini Indonesia masih mengimpor susu dan terus bertambah tiap tahunnya (Ginting, 2020; Riska et al., 2021). Besarnya jumlah impor susu nasional tersebut menunjukkan prospek pasar yang sangat besar dalam usaha peternakan sapi perah untuk menghasilkan susu segar sebagai produk substitusi impor (Pratiwi \& Hakim, 2013).

Pengembangan sapi perah di Indonesia sangat erat kaitannya dengan koperasi. Keduanya memiliki hubungan saling ketergantungan dan saling membutuhkan untuk menjaga eksistensi masing - masing (Guntoro \& Sulastri, 2012). Peternakan sapi perah baik sistem dan seluruh rantai produk susu menghadapi banyak hal teknis dan keterbatasan kelembagaan. Para peternak tidak mampu mendapatkan harga premium, sedangkan koperasi tidak mampu untuk mendapatkan pasokan susu yang berkualitas dari para peternak. Kualitas susu yang rendah juga mengakibatkan rendahnya harga yang diterima oleh peternak dan koperasi dari Industri Pengolahan Susu (IPS) (Resti et al., 2017; Sulastri \& Maharjan, 2002).

Peternak sapi perah di Indonesia memiliki kelemahan seperti cara beternak yang masih tradisional, produksi susu rendah, keterbatasan modal, kepemilikan ternak sedikit dan kesulitan dalam mengakses informasi mengenai inovasi (Mulatmi et al., 2016). Koperasi berperan penting dalam membantu mengatasi permasalahan tersebut dengan menyediakan berbagai fasilitas dan kemudahan. Koperasi melalui Gabungan Koperasi Susu Indonesia (GKSI) juga memperjuangkan kepentingan peternak agar memperoleh dukungan pemerintah dalam mengembangkan agribisnis sapi perah serta dalam hal negoisasi dengan IPS sehingga peternak dapat memperoleh harga susu yang layak (Martindah \& Saptati, 2006; Nurtini \& Muzayyanah, 2014; Safitri et al., 2021). Koperasi susu harus menjadi lembaga yang kuat, mandiri dan berdaya saing agar mampu menopang perkembangan persusuan Indonesia (Priyono \& Priyanti, 2015).

Kemandirian dalam menjalankan usaha penting dimiliki peternak untuk memenuhi tuntutan IPS dan era perdagangan bebas. Hal ini berkaitan dengan pengambilan keputusan, kreativitas serta kemampuan solusi pemecahan masalah dalam menjalankan usahanya. Dalam kegiatan usaha pertanian, kemandirian berkaitan dengan kemampuan petani dalam mengelola usahataninya guna menjamin kualitas produk dan keberlanjutan usahatani (Malta, 2016). 
Koperasi harus berupaya mengarahkan tingkah laku anggotanya agar memiliki kemandirian. Kemandirian mengartikan individu yang mampu mengambil inisiatif dengan tidak dipengaruhi oleh pihak lain dan mampu memanfaatkan segala sumberdaya yang dimiliki secara utuh untuk menyelesaikan permasalahan yang dihadapi (Susilowati et al., 2019). Kemandirian dapat diartikan sebagai suatu kondisi dari kehidupan masyarakat yang sudah dapat menentukan masa depan sendiri, memiliki kepercayaan diri dalam upaya pemenuhan kebutuhan hidup, serta sudah memiliki standar kehidupan yang layak. Kemampuan tersebut bermanfaat untuk menghadapi berbagai masalah, termasuk dalam mencari, menemukan dan melaksanakan solusi pengambilan keputusan (Usman, 2010).

Kemandirian yang dimiliki peternak akan membantu untuk memahami bahwa dirinya adalah modal utama untuk mencapai tujuan, sehingga selanjutnya peternak akan mampu mengelola sumber daya yang dimiliki dan mampu memenuhi kebutuhan dasar mereka sendiri (Fonchingong \& Fonjong, 2003). Namun sayangnya penelitian mengenai kemandirian peternak sapi perah di Daerah Istimewa Yogyakarta belum pernah dilakukan, sedangkan dengan menganalisis tingkat kemandirian peternak dapat dilakukan evaluasi terhadap kemampuan peternak dalam pengambilan keputusan, kreativitas, serta kemampuan solusi pemecahan masalah.

Berdasarkan berbagai latar belakang diatas penelitian mengenai kemandirian peternak sapi perah di Daerah Istimewa Yogyakarta penting untuk dilakukan. Rumusan permasalahan penelitian yaitu bagaimanakah kemandirian peternak sapi perah sebagai anggota koperasi dan faktorfaktor apa sajakah yang berpengaruh terhadap kemandirian tersebut. Penelitian ini bertujuan menganalisis tingkat kemandirian peternak sapi perah sebagai anggota koperasi dan mengetahui faktor-faktor yang berpengaruh terhadap kemandirian peternak sapi perah. Analisis kemandirian peternak tersebut diharapkan dapat memberikan manfaat untuk mengembangkan dan menguatkan posisi peternak baik terhadap tuntutan IPS maupun era perdagangan bebas.

Penelitian dilakukan di Koperasi Susu Warga Mulya Kabupaten Sleman, Daerah Istimewa Yogyakarta. Penentuan lokasi penelitian didasarkan bahwa Sleman merupakan wilayah pengembangan sapi perah di Daerah Istimewa Yogyakarta. Penentuan responden berdasarkan metode convenience sampling dengan lokasi peternak yang mudah dan aman di jangkau oleh peneliti. Metode ini memungkinkan peneliti untuk memiliki kebebasan untuk memilih siapa saja yang ditemui untuk menjadi responden sesuai dengan tujuan penelitian (Cooper \& Schindler, 2014). Pemilihan metode convenience sampling ini mengingat bahwa peternak sapi perah anggota Koperasi Susu Warga Mulya berada di kawasan lereng Gunung Merapi yang termasuk dalam kawasan rawan bencana dan akses jalan yang sulit dilalui. Berdasarkan kondisi tersebut diperoleh 52 peternak sapi perah anggota Koperasi Susu Warga Mulya sebagai responden penelitian. Alat bantu pengumpulan data dengan menggunakan kuesioner yang telah teruji validitas dan reliabilitasnya.

Data yang digunakan dalam penelitian ini meliputi data primer dan data sekunder. Pengumpulan data primer akan menggunakan dua teknik, yaitu: 1) Observasi, yaitu pengumpulan data dengan cara mengamati secara langsung obyek penelitian, dan 2) Wawancara, yaitu pengumpulan data dengan cara meminta keterangan dari responden. Data sekunder dikumpulkan dengan menggunakan teknik pencatatan; yaitu pengumpulan data dengan cara mencatat data yang telah ada pada koperasi atau instansi yang terkait dalam penelitian ini.

Kemandirian peternak dinilai berdasarkan indikator pengambilan keputusan, kreativitas dan solusi pemecahan masalah. Pada setiap indikator tersebut terdapat beberapa item pernyataan untuk mengukur kemandirian peternak. Teknik penentuan skor untuk mengukur kemandirian peternak yaitu dengan menggunakan skala likert. Pemilihan likert didasarkan pada pendapat Bryman (2012) yang menyebutkan skala dapat digunakan dalam pernyataan sikap individu. Skala likert 
ditetapkan melalui pendekatan deviasi normal dengan tujuan untuk memberi skor dari masing-masing jawaban.

Untuk menguji pengaruh karakteristik peternak yang meliputi umur, pendidikan peternak, kepemilikan betina produktif dan pengalaman beternak terhadap kemandirian peternak, maka dilakukan uji regresi dengan formula sebagai berikut :

$$
Y=A+b_{1} X_{1}+b_{2} X_{2}+b_{3} X_{3+} b_{4} X_{4+} e
$$

Keterangan :

$\mathrm{Y}=$ Kemandirian peternak sapi perah

A $\quad=$ Nilai konstanta

$b_{1}, b_{2}, b_{3}$

dan $b_{4}=$ Koefisien regresi

$\mathrm{X}_{1}=$ Umur (tahun)

$\mathrm{X}_{2} \quad=$ Pendidikan peternak (tahun)

$\mathrm{X}_{3}=$ Kepemilikan betina produktif (ekor)

$\mathrm{X}_{4} \quad=$ Pengalaman beternak (tahun)

e $\quad=$ error

\section{PEMBAHASAN}

\section{Karakteristik Peternak}

Pada penelitian ini karakteristik peternak yang diperoleh antara lain : umur, tingkat pendidikan, kepemilikan betina produktif dan pengalaman beternak (Tabel 1). Berbagai karakteristik tersebut dapat menjelaskan kapasitas diri yang dimiliki peternak, hal ini juga menentukan kualitas sumber daya manusia pada anggota Koperasi Susu Warga Mulya, Kabupaten Sleman, Daerah Istimewa Yogyakarta.

Mayoritas peternak sapi perah $(71,15 \%)$ berada pada rentang 26 tahun hingga 65 tahun. Hasil ini menunjukkan bahwa sebagian besar peternak berada pada rentang usia produktif. Individu dikatakan berada memiliki usia produktif jika berusia pada rentang 15 tahun hingga 65 tahun (Nurdiyansah et al., 2020). Usia peternak memegang peran penting dalam kegiatan usaha pemeliharaan sapi perah. Peternak pada usia produktif lebih berpeluang untuk dapat memberikan kontribusi baik pikiran maupun tenaga untuk peningkatan produktivitas peternakan. Pada usia produktif peternak juga akan lebih mampu untuk mengkoordinasikan dan mengambil keputusan yang efektif bagi kemajuan usaha, selain itu usia produktif juga berdampak pada tingkat kemandirian peternak untuk tidak bergantung meminta bantuan orang lain (Harmoko et al., 2020; Prawira et al., 2015).

Karakteristik pendidikan merupakan lama tahun pendidikan formal yang diperoleh peternak. Sebanyak $44,23 \%$ peternak memperoleh pendidikan selama 9 tahun atau setara dengan tingkat Sekolah Menengah Pertaman (SMP). Sementara itu hanya 17,31\% peternak yang mampu memperoleh pendidikan hingga 12 tahun, atau pada tingkat Sekolah Menengah atas (SMA). Tingkat pendidikan peternak berpengaruh terhadap kemampuan dan cara berfikir yang dimiliki (Nurdiyansah et al., 2020). Berdasarkan hasil ini dapat dikatakan bahwa sebagian besar pendidikan peternak relatif rendah.

Sebagian besar peternak $(69,23 \%)$ hanya memiliki betina produktif pada skala 1 hingga 5 ekor. Peternak yang memiliki betina produktif pada rentang 6 hingga 10 ekor hanya sebanyak 15,38\%. Pembagian skala usaha sapi perah dilakukan berdasarkan kepemilikan betina produktif, yaitu skala usaha dikatakan kecil pada kepemilikan betina produktif sampai dengan 5 ekor dan skala besar pada kepemilikan lebih dari 5 ekor (Asmara et al., 2016). Maka dapat dikatakan mayoritas usaha peternakan sapi perah yang dijalankan anggota Koperasi Susu Warga Mulya berskala kecil dan belum ekonomis. Pamela et al. (2017) menjelaskan bahwa semakin tinggi jumlah kepemilikan sapi betina produktif (laktasi) maka semakin tinggi pula tingkat tingkat keberhasilan usaha peternakan sapi perah.

Tabel 1.

Karakteristik Peternak Sapi Perah

\begin{tabular}{l|l|l}
\hline $\begin{array}{c}\text { Karakteristik } \\
\text { Peternak }\end{array}$ & Jumlah & Persentase (\%) \\
\hline Umur (tahun) & 37 & 71,15 \\
\hline $26-65$ & 15 & 28,85 \\
\hline$>65$ & 9 & 17,31 \\
\hline Pendidikan (tahun) & 9 & 15,38 \\
\hline$\leq 6$ & 8 & 44,23 \\
\hline 6 & 23 &
\end{tabular}




\begin{tabular}{l|l|l}
\hline $\begin{array}{c}\text { Karakteristik } \\
\text { Peternak }\end{array}$ & Jumlah & Persentase (\%) \\
\hline 12 & 9 & 17,31 \\
\hline$>12$ & 3 & 5,77 \\
\hline \multicolumn{3}{|c}{ Kepemilikan betina produktif (ekor) } \\
\hline $1-5$ & 36 & 69,23 \\
\hline $6-10$ & 8 & 15,23 \\
\hline $11-15$ & 7 & 13,47 \\
\hline$>16$ & 1 & 1,92 \\
\hline Pengalaman Beternak (tahun) \\
\hline $1-5$ & 7 & 13,47 \\
\hline $6-10$ & 24 & 46,15 \\
\hline$>10$ & 21 & 40,38 \\
\hline
\end{tabular}

Sumber : Analisis data primer, 2021.

Pengalaman beternak menjelaskan lama tahun peternak dalam menjalankan usaha sapi perah. Sebanyak $46,15 \%$ peternak memiliki lama pengalaman berternak antara 6 tahun hingga 10 tahun, sedangkan 40,38\% memiliki lama pengalaman beternak sapi perah lebih dari 10 tahun. Pengalaman beternak akan memberikan berbagai pelajaran bagi peternak atas apa yang telah dia jalankan dalam usahanya. Sejatinya semakin lama pengalaman beternak yang dimilki peternak, akan membuat peternak semakin bijak dalam mengambil keputusan. Oleh sebab itu, peternak harus memiliki pengalaman beternak yang cukup untuk mengambil segala kebijakan dalam menjalankan usahanya (Nurdiyansah et al., 2020).

Hasil karakteristik peternak yang diperoleh secara keseluruhan sesuai dengan Mulatmi et al. (2016) bahwa kelemahan peternakan sapi perah yaitu pendidikan peternak yang rendah dan kepemilikan ternak sedikit, namun memiliki kekuatan dimana peternak berada pada usia produktif dengan pengalaman beternak cukup lama. Maka dengan demikian diharapkan bahwa peternak sapi perah anggota Koperasi Susu Warga Mulya dapat lebih mandiri untuk menjalan usaha yang efektif dan efisien.

\section{Indikator Kemandirian: Pengambilan Keputusan}

Kegiatan usaha di bidang apapun memerlukan keputusan dalam setiap prosesnya. Keputusan tersebut diperlukan untuk memutuskan aktivitas yang akan dikerjakan dalam kegiatan usaha. Begitu juga dalam usaha sapi perah, keputusan merupakan sebuah kemampuan peternak dalam merencanakan dan menjalankan proses produksi. Pada kegiatan pertanian pengambilan keputusan termasuk pada manajemen harian yang berkaitan dengan kegiatan teknis yang akan dilakukan. Hal ini tentunya akan berdampak pada keberlanjutan usaha pertanian (Daydé et al., 2014).

Peternak dalam usaha sapi perah tentunya memiliki peran sebagai manajer, pemelihara ternak sekaligus sebagai individu yang otonom. Peran sebagai manager mengharuskan peternak untuk dapat memahami dan melakukan fungsi perencanaan dan pengambilan keputusan, penyelenggaraan, kepemimpinan dan kontrol. Maka idealnya peternak dapat melakukan pengambilan keputusan yang tepat agar usaha sapi perahnya mencapai keberhasilan atau semakin berkembang (Van Fleet et al., 2014; Yunasaf et al., 2008). Berikut capaian skor kemandirian peternak dalam membuat keputusan dalam usaha sapi perah pada Tabel 2.

Tabel 2.

Tingkat Capaian Peternak Dalam Mengambil Keputusan

\begin{tabular}{|c|c|c|c|c|}
\hline No & Item & $\begin{array}{c}\text { Skor } \\
\text { Maksimal }\end{array}$ & $\begin{array}{c}\text { Rata - } \\
\text { rata }\end{array}$ & $\begin{array}{c}\% \\
\text { Skor }\end{array}$ \\
\hline 1 & Mengambil keputusan sendiri dalam memilih usaha sapi perah & 2 & 1,32 & 66,00 \\
\hline 2 & Mengambil keputusan sendiri ketika memilih bibit ternak sapi perah & 3 & 1,76 & 58,67 \\
\hline 3 & Mengambil keputusan sendiri ketika menggunakan obat-obatan & 2 & 0,50 & 25,00 \\
\hline 4 & Mengambil keputusan sendiri ketika memilih jenis pakan & 2 & 1,29 & 64,50 \\
\hline 5 & Mengambil keputusan sendiri ketika melakukan penjualan susu & 2 & 0,79 & 39,50 \\
\hline \multicolumn{2}{|r|}{ Jumlah } & 11 & 5,66 & \\
\hline
\end{tabular}

Sumber : Analisis data primer, 2021. 
Secara umum peternak mengambil keputusan secara individu untuk memilih usaha sapi perah menjadi usahanya, skor yang dicapai adalah 66,00\%. Berdasarkan persentase tersebut maka sebagian besar peternak mampu mengambil keputusan sendiri untuk memilih usaha sapi perah. Hasil ini menunjukkan bahwa keputusan yang diambil merupakan bentuk tindakan individu setelah mempertimbangkan sumberdaya yang dimiliki yang dapat digunakan sebagai modal produksi. Namun, peternak secara umum belum mampu mengambil keputusan sendiri dalam penggunaan obat-obatan untuk ternaknya. Indikasi ini ditunjukkan capaian skor hanya $25,00 \%$. Pada umumnya peternak akan melakukan konsultasi baik kepada pihak Koperasi Susu Warga Mulya, petugas penyuluh lapangan maupun bertanya kepada sesama peternak untuk menggunakan obat - obatan.

Peternak juga belum mampu mengambil keputusan sendiri dalam melakukan penjualan susu, ditunjukkan dengan capaian skor yang $39,40 \%$. Peternak mengalami ketidakmandirian dalam penjualan susu. Hal ini sesuai dengan temuan Resti et al. (2017) bahwa peternak dan koperasi tergantung pada Industri Pengolahan Susu (IPS) dalam hal harga susu dan sama sekali tidak terlibat dalam penentuan harga susu. Industri Pengolahan Susu (IPS) merupakan penentu langsung harga susu dalam negeri. Harga yang diberikan kepada peternak sesuai dengan kualitas susu yang dihasilkan. Namun sayangnya, mayoritas kualitas susu yang dihasilkan peternak sapi perah rakyat belum mencapai standart kualitas susu yang dibutuhkan oleh industri (Safitri et al., 2021). Oleh sebab itu posisi tawar peternak dalam menentukan harga susu terhadap industri sangat lemah. Indikator mampu mengambil keputusan secara keseluruhan dapat dilihat pada distribusi jumlah petani dalam Tabel 3 berikut.

Tabel 3.

Distribusi Peternak Dalam Mengambil Keputusan

\begin{tabular}{lllll}
\hline No & Kategori Mengambil Keputusan & Capaian Skor & Peternak (orang) & Persentase (\%) \\
\hline 1 & Rendah & $0-3,66$ & 14 & 26,92 \\
2 & Sedang & $3,67-7,34$ & 36 & 69,23 \\
3 & Tinggi & $7,35-11,00$ & 2 & 3,85 \\
\hline \multicolumn{2}{l}{ Total } & & 52 & 100 \\
\hline
\end{tabular}

Sumber : Analisis data primer, 2021.

Peternak yang benar - benar mandiri dalam melakukan pengambilan keputuan hanya sebesar $3,85 \%$. Sementara itu mayoritas peternak $(69,23 \%)$ memiliki kategori pengambilan keputusan sedang. Kebanyakan peternak sapi perah belum memiliki kemampuan yang memadai untuk melakukan pengambilan keputusan demi mencapai keberhasilan usahanya (Nilamsari et al., 2017). Dalam pengambilan keputusan terkait usaha ternak, pada umumnya peternak akan berkonsultasi dan memprioritaskan informasi yang diperoleh berdasarkan sumber informasi itu sendiri seperti penyuluh, ketua kelompok, maupun sesama peternak (Mulatmi et al., 2019). Selain itu kemandirian peternak dalam pengambilan keputusan juga dipengaruhi oleh skala usaha (jumlah kepemilikan ternak)
(Rahmah \& Somanjaya, 2019). Skala usaha kecil mengakibatkan peternak tidak dapat melaksanakan usahanya secara efisien, Peternak akan bergantung kepada koperasi untuk penyerapan susu dan penetapan harga jual.

\section{Indikator Kemandirian : Kreativitas}

Kreativitas adalah sikap ataupun respon seseorang terhadap masalah kehidupan dengan cara yang segar dan baru (Sternberg, 2012). Kreativitas juga dapat diartikan membangun ide atau pemecahan masalah yang bernilai bagi individu maupun kelompok sosial yang lebih besar (Hennessey \& Amabile, 2010). Pada penelitian ini kreativitas mengarah kepada ide-ide yang dimiliki peternak dalam mengatasi permasalahan yang dihadapi. Ide- 
ide yang inovatif dapat menjadi jalan dalam memperoleh tujuan yang akan dicapai. Rasa tanggung jawab mendorong manusia untuk mengembangkan semangat dan kreativitasnya serta tidak merasa kelebihan sebagai alasan mendominasi (Sulastri et al., 2019).

Capaian skor peternak dalam memiliki kreatifitas disajikan dalam Tabel 4. Capaian skor dari indikator memiliki kreativitas tertinggi mencari informasi teknologi baru, skor yang dicapai adalah $52,00 \%$. Sedangkan terendah dalam indikator ini adalah melakukan pengolahan biogas, yaitu 34\%. Indikator memiliki cara sendiri dalam mengatasi permasalahan juga hanya mencapai 35,50\%. Indikasi tersebut menjelaskan bahwa peternak lebih memilih mencari ide dari sumber lain untuk memecahkan masalahnya.

Tabel 4.

Tingkat Capaian Peternak Dalam Kreativitas

\begin{tabular}{l|l|l|l|l}
\hline No & \multicolumn{1}{|c|}{ Item } & Skor maksimal & Rata - rata & \% Skor \\
\hline 1 & Memiliki cara sendiri dalam mengatasi permasalahan & 2 & 0,71 & 35,50 \\
2 & Mencari ide ketika terdapat masalah & 3 & 1,50 & 50,00 \\
3 & Melakukan pengolahan pupuk organik & 3 & 1,29 & 43,00 \\
4 & Melakukan pengolahan biogas & 2 & 0,68 & 34,00 \\
5 & Mencari informasi teknologi baru & 2 & 1,04 & 52,00 \\
6 & Memperluas pemasaran susu & 3 & 1,36 & 45,33 \\
\hline Jumlah & 15 & 6,58 & \\
\hline
\end{tabular}

Sumber : Analisis data primer, 2021.

Dalam pelaksanaan usaha sapi perah rakyat terdapat berbagai hambatan yang dihadapi oleh peternak seperti skala usaha kecil, produktivitas ternak rendah, ketersedian dan harga pakan, dan adopsi teknologi yang bertujuan untuk meningkatkan efisiensi usaha. Sebagai penyedia susu bagi Industri Pengolahan Susu (IPS) peternak rakyat juga mengahadapi permasalahan terkait dengan kualitas susu yang tidak memenuhi standar IPS (Nurtini \& Muzayyanah, 2014). Peternak rakyat tentunya tidak akan mampu untuk menyelesaikan berbagai permasalahan tersebut secara sendiri. Maka peternak akan cenderung mencari cara, ide atau informasi untuk dapat membantu mengatasi permasalahannya melalui konsultasi dengan sesama peternak, penyuluh maupun pihak koperasi. Sebagaimana hasil indikator mencari ide ketika mendapat masalah memperoleh mencapai 50,00\% dan indikator mencari informasi teknologi terbaru mencapai $52 \%$. Sebaran peternak berdasarkan kategori kreativitas disajikan dalam Tabel 5.

Tabel 5.

Distribusi peternak dengan kreativitas

\begin{tabular}{l|l|l|l|l}
\hline No & \multicolumn{1}{|c|}{ Kategori Kreativitas } & \multicolumn{1}{|c|}{ Capaian Skor } & \multicolumn{1}{|c|}{ Peternak (orang) } & \multicolumn{1}{c}{ Persentase (\%) } \\
\hline 1 & Rendah & $0-5,00$ & 14 & 26,93 \\
2 & Sedang & $5,01-10,00$ & 30 & 57,69 \\
3 & Tinggi & $10,01-15,00$ & 8 & 15,38 \\
\hline & Total & & 52 & 100 \\
\hline
\end{tabular}

Sumber : Analisis data primer, 2021.

Sebagian besar peternak memiliki kreativitas dalam usaha sapi perah pada kategori sedang (57,69\%). Kategori kreativitas tinggi hanya dicapai oleh 15,38\% peternak. Peternak sapi perah hingga saat ini berada pada posisi tawar yang lemah diantara mata rantai produksi dan pemasaran (Sudaryanto \& Hermawan, 2014). Kondisi tersebut membuat peternak menghadapi ketidakmampuan dalam penyelesaian masalah secara mandiri 
seutuhnya. Berdasarkan hasil mengindikasikan bahwa pada umumnya peternak akan mencari ide-ide kreatif untuk mengatasi masalah. Hal ini juga menunjukkan peternak menyadari bagaimana kondisi dan posisi mereka, dan langkah apa yang harus mereka ambil untuk memperoleh ide agar dapat menyelesaikan masalahnya. Dengan memiliki ide kreatifitas segala permasalahan dapat diatasi melalui jalan keluar yang inovatif.

Kurang berkembangnya potensi kreativitas peternak selama ini dikarenakan peternak ditempatkan sebagai obyek dalam pembangunan (Simamora, 2020). Sudut pandang ini perlu dirubah dimana peternak adalah pelaku usaha peternakan, sehingga dalam identifikasi dan penyelesaian masalah peternak harus ditempatkan subyek bersama dengan pemerintah maupun koperasi susu. Hal ini akan mendorong peternak untuk menganalisis permasalahannya, mengetahui kebutuhannya dan menemukan ide pemecahan masalah. Maka dengan mampunya peternak menemukan ide maka kreativitas peternak akan meningkat. Winarso (2010) berpendapat dalam mengatasi permasalahan yang dihadapi oleh peternak diperlukan adanya peraturan pemerintah yang dibuat sedemikian rupa untuk dapat meningkatkan kreativitas dan daya kerja peternak.

\section{Indikator Kemandirian: Solusi Pemecahan Masalah}

Peternak sebagai manajer dalam kegiatan usaha sapi perahnya dituntut memiliki kemandirian dalam mencari solusi. Solusi tersebut diperlukan untuk mengatasi dan menanggulangi permasalahan yang dihadapi peternak. Setiap permasalahan bersifat unik sehingga tidak ada solusi yang bersifat umum (Van Fleet et al., 2014). Maka peternak perlu terus mencari solusi untuk mengatasi permasalahannya. Indikator solusi pemecahan masalah (Tabel 6) menjelaskan kemampuan peternak untuk mencari solusi permasalahan.

Tabel 6.

Tingkat capaian peternak dalam mencari solusi pemecahan masalah

\begin{tabular}{l|l|l|l|l}
\hline No & \multicolumn{1}{|c|}{ Indikator Mencari Solusi } & Skor maksimal & Rata-rata & \% Skor \\
\hline 1 & Diskusi bersama peternak lain & 3 & 2,21 & 73,64 \\
2 & Pertemuan kelompok ternak & 3 & 1,50 & 50,00 \\
3 & Keputusan anggota keluarga & 3 & 1,32 & 44,00 \\
4 & Mengikuti pertemuan dalam lingkungan masyarakat & 2 & 1,67 & 83,50 \\
5 & Pendapat penyuluh pertanian & 3 & 1,50 & 50,00 \\
6 & Melalui informasi & 3 & 1,62 & 54,00 \\
7 & Ide sendiri & 2 & 1,40 & 70,00 \\
\hline \multicolumn{2}{l|}{ Jumlah } & 19 & 11,22 & \\
\hline
\end{tabular}

Sumber : Analisis data primer, 2021.

Peternak dalam mencari solusi melalui forum pertemuan dalam lingkungan masyarakat, skor yang dicapai 83,50\%. Diskusi dengan peternak lain menjadi urutan berikut dengan capaian skor $73,64 \%$. Indikasi ini menunjukkan bahwa sebagian besar peternak dalam memecahkan masalah dan mencari solusi diperoleh melalui pertemuan-pertemuan dalam lingkungan masyarakat maupun berdiskusi dengan peternak lain. Forum pertemuan dalam lingkungan masyarakat memungkinkan peternak untuk dapat memperoleh berbagai alternatif solusi pemecahan masalah dalam kelompok yang lebih besar. Berdiskusi dengan peternak lain cenderung mengarah kepada bertukar pengalaman sesama peternak, melalui hal tersebut peternak cenderung merasa lebih mudah untuk menemukan solusi. 
Tabel 7.

Distribusi peternak dalam mencari solusi

\begin{tabular}{l|l|l|l|l}
\hline No & \multicolumn{1}{|c|}{ Kategori Mencari Solusi } & \multicolumn{1}{c}{ Capaian Skor } & Peternak (orang) & Persentase (\%) \\
\hline 1 & Rendah & $0-6,33$ & 5 & 9,62 \\
2 & Sedang & $6,34-12,66$ & 29 & 55,76 \\
3 & Tinggi & $12,67-19,00$ & 18 & 34,62 \\
\hline \multicolumn{2}{l}{ Total } & 52 & 100 \\
\hline
\end{tabular}

Sumber : Analisis data primer, 2021.

Indikator dalam mencari solusi memiliki sebaran peternak dalam kategori rendah, sedang dan tinggi. Berikut distribusi peternak dalam mencari solusi disajikan dalam Tabel 7. Dari tabel tersebut diketahui bahwa peternak sebagian besar mampu mencari solusi. Kategori sedang dan tinggi dalam mencari solusi mencapai masing-masing 55,76\% dan 34,62\% Peternak secara umum mampu mencari solusi yang dihadapi dalam kegiatan beternaknya. Bentuk-bentuk solusi yang diperoleh peternak umumnya berupa saran masukan, pendapat atau pengalaman-pengalaman yang diperoleh dari diskusi yang diselenggarakan dalam masayarakat dan kelompok tani.

\section{Tingkat Kemandirian Peternak}

Kemandirian dalam konteks pemberdayaan masyarakat merupakan tingkat kemajuan yang harus dicapai sehingga masyarakat dapat membangun dan memelihara kelangsungan hidupnya dengan kekuatannya sendiri secara berkelanjutan (Noor, 2011). Kemandirian dalam bentuk lain yang lebih penting adalah kemampuan dalam menghadapi berbagai masalah, termasuk dalam mencari, menemukan dan melaksanakan solusi pengambilan keputusan dalam mengatasi masalah yang dihadapi. Kemandirian peternak mengartikan peternak mampu untuk mengambil keputusan, kreatif dan mampu mencari solusi pemecahan masalah demi tercapainya efesiensi usaha peternakan mereka. Kategori kemandirian peternak dibedakan dalam kategori rendah, sedang dan tinggi (Tabel 8).

Tabel 8.

Distribusi kemandirian peternak dalam usaha sapi perah

\begin{tabular}{l|l|l|l|l}
\hline No & \multicolumn{1}{|c|}{ Kategori Kemandirian } & \multicolumn{1}{|c|}{ Capaian Skor } & \multicolumn{1}{|c|}{ Peternak (orang) } & Persentase (\%) \\
\hline 1 & Rendah & $0-15,00$ & 4 & 7,70 \\
2 & Sedang & $15,01-30,00$ & 40 & 76,92 \\
3 & Tinggi & $30,01-45,00$ & 8 & 15,38 \\
\hline
\end{tabular}

Sumber : Analisis data primer, 2021.

Secara umum tingkat kemandirian peternakdalam usaha sapi perah dalam kategori sedang $(76,92 \%)$. Indikasi tersebut menjelaskan bahwa secara umum peternak memiliki cukup kemandirian dalam usaha sapi perahnya. Kemandirian peternak dalam pengambilan keputusan masih terkendala dalam penentuan harga jual susu. Pada penentuan harga jual susu, peternak dan koperasi sangat bergantung pada IPS. Kemandirian peternak dari indikator kreativitas menunjukkan bahwa peternak telah cukup berupaya dalam mencari ide ketika terdapat masalah dan mencari informasi teknologi terbaru. Peternak akan lebih memilih untuk mencari ide dari sumber lain untuk memecahkan masalahnya. Hal ini juga ditunjukkan dalam kemandirian solusi pemecahan masalah, dimana secara umum peternak akan berdiskusi bersama peternak lain maupun mengikuti pertemuan dalam lingkungan masyarakat untuk menemukan solusi permasalan yang dihadapinya.

Pengembangan peternakan sapi perah memiliki berbagai kerentanan yang telah 
diketahui bersama meliputi harga jual susu segar, kebijakan pemerintah, kebijakan kelompok, dan moralitas peternak di dalam kelompok (Amam \& Harsita, 2019). Namun pengembangan peternakan sapi perah juga memiliki peran strategis dalam meningkatkan kualitas sumber daya manusia didalamnya yaitu termasuk peternak. Maka dalam hal ini perlunya membangun sudut pandang bahwa peternak juga merupakan subyek dalam pengembangan peternakan sapi perah. Mayoritas peternak memiliki kategori kemandirian peternak sedang juga menunjukkan bahwa peternak tetap memerlukan dukungan dari berbagai pihak untuk menyelesaikan permasalahannya. Dengan demikian peningkatan kemandirian peternak dalam pengembangan peternakan sapi perah perlu dilakukan agar membantu mengatasi kerentanan diatas.

Peternak yang mandiri diharapkan akan memiliki posisi tawar lebih baik dalam persaingan harga, kualitas, dan produksi susu dengan susu impor. Koperasi susu sebagai lembaga terdekat dengan peternak perlu memperkuat perannya dalam peningkatan kualitas sumber daya manusia peternak dan membantu peternak dalam penerapan teknologi demi tercapainya efisiensi usaha dan susu yang dihasilkan berkualitas. Perluasan pemasaran susu maupun pengolahan susu juga perlu dilakukan oleh koperasi untuk mengurangi ketergantungan terhadap IPS baik dari segi harga maupun penyerapan susu segar.

\section{Faktor Kemandirian Peternak}

Karakteristik peternak memberikan gambaran kondisi peternak secara keseluruhan. Kondisi yang dimiliki oleh peternak tentunya akan mempengaruhi kemandirian yang dimilikinya. Maka analisis regresi dilakukan untuk mengetahui pengaruh karakteristik terhadap kemandirian peternak (Y). Tabel 9 menunjukkan nilai $\mathrm{R}^{2}$ sebesar 0,319 yang berarti prediksi variabel-variabel umur $\left(X_{1}\right)$, pendidikan $\left(X_{2}\right)$, kepemilikan betina produktif $\left(X_{3}\right)$ dan pengalaman beternak $\left(X_{4}\right)$ sebesar $31,9 \%$. Sisanya sebesar $68,1 \%$ dijelaskan dari luar model. Nilai Konstanta $(0,124)$ yang dihasilkan positif yang berarti, semakin besar nilai koefisien variabel independen maka kemandirian akan tinggi. Sehingga persamaan regresi yang dihasilkan adalah : $Y=0,124+$ $0,151 X_{1}+0,170 X_{2}+0,448 X_{3}+0,656 X_{4}$

Tabel 9.

Hasil Analisis Regresi

\begin{tabular}{l|l|l|l}
\hline No. & \multicolumn{1}{|c|}{ Variabel } & Koefisien Regresi & Signifikansi \\
\hline 1 & Umur peternak & 0,151 & 0,478 \\
2 & Pendidikan peternak & 0,170 & 0,419 \\
3 & Kepemilikan betina produktif & 0,448 & $0,005^{*}$ \\
4 & Pengalaman beternak & 0,656 & 0,883 \\
\hline
\end{tabular}

Sumber : Analisis data primer, 2021.

${ }^{*}(p \leq 0,01)$

Konstanta $=0,124$

$\mathrm{R}^{2} \quad=0,319$

$F_{\text {hitung }}=5,037(p \leq 0,01)$

Tabel 9 menunjukkan bahwa jumlah kepemilikan betina produktif merupakan satu-satunya faktor yang berpengaruh positif secara signifikan $(\mathrm{p} \leq 0,01)$ pada kemandirian peternak. Jumlah kepemilikan betina produktif menunjukkan skala usaha yang dilakukan oleh peternak. Rahmah \& Somanjaya (2019) menjelaskan bahwa skala usaha merupakan faktor yang mempengaruhi pengambilan keputusan peternak dalam tatalaksana pemeliharaan. Skala usaha kecil cenderung dilaksanakan dalam tatalaksana pemeliharaan tradisional dan penerapan teknologi oleh peternak akan rendah. Sebagaimana hasil diperoleh bahwa $69,23 \%$ peternak sapi perah skala usaha kecil (kepemilikan betina produktif 1 hingga 5 ekor) dan penerapan teknologi seperti pengolahan pupuk organik hanya 
mencapai skor $43 \%$ dan penerapan biogas 34\% (Tabel 3).

Peningkatan skala usaha sehingga dapat mendorong peternak mengambil keputusan maupun kreativitas untuk menerapkan teknologi dalam usahanya (Suciani et al., 2015). Kepemilikan betina produktif yang banyak juga akan memberikan jumlah produksi yang tinggi sehingga menuntut peternak mencari solusi baik untuk penerapan teknologi maupun perluasan penjualan susu segar. Dengan demikian semakin banyak kepemilikan betina produktif maka semakin tinggi kemandirian peternak.

Upaya peningkatan kepemilikan betina produktif dapat dilakukan dengan penguatan peran koperasi sebagaimana yang telah disebutkan yaitu meliputi penyediaan sarana dan prasana pemeliharaan, akses modal maupun fasilitas simpan pinjam, pelayanan kesehatan ternak, dan pembangunan kapasitas peternak, tentunya diperlukan kajian yang lebih mendalam. Hal ini diperlukan mengingat bahwa koperasi merupakan lembaga penggerak laju ekonomi dan pemberdayaan dengan tujuan utama meningkatkan kesejahteraan peternak (Safitri et al., 2021). Proses pembangunan kapasitas peternak perlu dilakukan koperasi melalui penyuluhan dan pelatihan sehingga dapat membangun sikap kreatif dan professional peternak, serta mengembangkan mental peternak dalam mengambil keputusan untuk mengatasi ancaman ekonomi maupun sosial (Riswara et al., 2015). Terbentuknya kapasitas peternak tersebut berdasarkan peran koperasi akan membantu peternak memiliki kemandirian dalam menjalankan usahanya.

\section{SIMPULAN}

Berdasarkan karakteristik peternak diketahui bahwa mayoritas peternak memiliki tingkat pendidikan rendah dan kepemilikan ternak menunjukkan skala usaha yang dijalankan kecil, namun demikian peternak didominasi pada usia produktif dengan pengalaman beternak cukup lama. Tingkat kemandirian peternak dalam usaha sapi perah mayoritas pada kategori sedang (76,92\%). Indikasi tersebut menjelaskan bahwa secara umum peternak memiliki cukup kemandirian dalam usaha sapi perahnya. Peternak juga masih memerlukan dukungan dari berbagai pihak untuk menyelesaikan kendala yang dihadapi. Kendala yang dihadapi peternak terutama terkait pengambilan keputusan pada penentuan harga jual susu yang masih bergantung pada IPS. Koperasi susu dalam hal ini perlu memperkuat perannya untuk meningkatkan kemandirian peternak sehingga dapat mengurangi ketergantungan terhadap IPS baik dari segi harga maupun penyerapan susu segar. Faktor yang mempengaruhi kemandirian peternak yaitu kepemilikan betina produktif $(p \leq 0,01)$ berdasarkan hasil analisis regresi. Peningkatan jumlah betina produktif yang dipelihara peternak akan secara positif berpengaruh terhadap kemandirian peternak.

\section{DAFTAR PUSTAKA}

Amam, A., dan Harsita, P. A. (2019). Aspek Kerentanan Usaha Ternak Sapi Perah di Kabupaten Malang. Agrimor, 4(2), 26-28. https://doi.org/10.32938/ ag.v4i2.663

Asmara, A., Purnamadewi, Y. L., dan Lubis, D. (2016). Keragaan Produksi Susu Dan Efisiensi Usaha Peternakan Sapi Perah Rakyat di Indonesia. Jurnal Manajemen Dan Agribisnis, 13(1), 14-25. https://doi.org/10.17358/ jma.13.1.14

Bryman, A. (2012). Social Research Methods (4th ed.). New York: Oxford University Press Inc.

Cooper, D. R., and Schindler, P. S. (2014). Business Research Methods (12th ed.). New York: McGraw-Hill Irwin.

Daydé, C., Miat, U. R., Miat, U. R., Miat, U. R., Martin-clouaire, R., and Miat, U. R. (2014). Investigating Operational Decision-Making in Agriculture. 7 th International Environmental Modelling and Software Society, 2188-2195. San Diego, California, USA: Brigham Young University.

Fonchingong, C. C., and Fonjong, L. N. (2003). The concept of self-reliance in community development initiatives 
in the Cameroon grassfields. GeoJournal, 57(1/2), 83-94. https:// doi.org/10.1023/a:1026042718043

Ginting, L. N. (2020). Analisis Daya Saing Susu Sapi Segar Dalam Negeri. Jurnal Ekonomi Pertanian Dan Agribisnis (JEPA), 4(4), 774-782.

Guntoro, B., dan Sulastri, E. (2012). Peran Pemerintah dan Lembaga Perkoperasian P ada Pengembangan Sapi Perah Pasca Bencana Erupsi Merapi 2010 Di Provinsi Daerah Istimewa Yogyakarta. In Merapi Dalam Kajian Multidisiplin, Sumbangan Pemikiran Sekolah Pascasarjana UGM Bagi Korban Erupsi Merapi Tahun 2010. Yogyakarta: Sekolah Pascasarjana Universitas Gadj ah Mada.

Harmoko, Ibrahim, Kusrianty, N., dan Marhayani. (2020). Gambaran Struktur Populasi Ternak Kambing di Kecamatan Galang Kabupaten Tolitoli. Jurnal Ilmiah Cendekia Eksakta, 5(2), 121-125.

Hennessey, B. A., and Amabile, T. (2010). Creativity. Annual Review of Psychology, 61, 569-598.

Malta. (2016). Faktor - Faktor yang Berhubungan dengan Kemandirian Petani dalam Pengambilan Keputusan untuk Keberlanjutan Usahatani (Kasus Petani di Desa Sukaharja - Kabupaten Bogor). Cakrawala - Jurnal Humaniora, 18(2). https://doi.org/10.24198/ sosiohumaniora.v18i2.9945

Martindah, E., dan Saptati, R. A. (2006). Peran Dan Upaya Koperasi Peternak Sapi Perah Dalam Meningkatkan Kualitas Susu Di Jawa Barat. Semiloka Nasional Prospek Industri Sapi Perah Menuju Perdagangan Bebas - 2020, 476-483.

Mulatmi, S. N. W., Anggraini, A. D., dan Prima, A. (2019). Jejaring Sosial dan Diseminasi Teknologi Tepat Guna pada Peternakan Sapi Perah di Daerah Istimewa Yogyakarta. Jurnal Sain Peternakan Indonesia, 14(2), 137-
144. https://doi.org/https://doi. org/10.31186/jspi.id.14.2.137-144

Mulatmi, Septi Nur Wulan, Guntoro, B., Widyobroto, B. P., Nurtini, S., dan Pertiwiningrum, A. (2016). Strategi Peningkatan Adopsi Inovasi pada Peternakan Sapi Perah Rakyat di Daerah Istimewa Yogyakarta, Jawa Tengah, dan Jawa Timur. Buletin Peternakan, 40(3), 219. https://doi. org/10.21059/buletinpeternak. v40i3.12470

Nilamsari, N., Saleh, A., Hubeis, M., dan Pandjaitan, N. K. (2017). Komunikasi Program Corporate Social Responsibility Industri pengolahan susu untuk pemberdayaan peternak sapi perah. Jurnal ASPIKOM, 3(2), 296-310.

Noor, M. (2011). Pemberdayaan Masyarakat. Jurnal Ilmiah CIVIS, 1(2).

Nurdiyansah, I., Suherman, D., dan Putranto, D. (2020). Hubungan Karakteristik Peternak dengan Skala Kepemilikan Sapi Perah di Kecamatan Kabawetan Kabupaten Kepahiang. Buletin Peternakan Tropis, 1(2), 64-72.

Nurtini, S., dan Muzayyanah, M. A. U. (2014). Profil Peternakan Sapi Perah Rakyat di Indonesia. Yogyakarta: Gadjah Mada University Press.

Pamela, P., Pambudy, R., dan Winandi, R. (2017). Kompetensi Kewirausahaan dengan Keberhasilan Usaha Peternak Sapi Perah Pujon, Malang. Jurnal Agribisnis Indonesia, 4(1), 57. https:/ / doi.org/10.29244/jai.2016.4.1.57-66

Pratiwi, H., \& Hakim, A. (2013). Perilaku Impor Susu Indonesia. Telaah Bisnis, 14(1), 53-70. Retrieved from http:// journal.stimykpn.ac.id/index.php/ $\mathrm{tb} /$ article/view/14

Prawira, H. Y., Muhtarudin, dan Sutrisna, R. (2015). Potensi Pengembangan Peternakan Sapi Potong di Kecamatan Tanjung Bintang Kabupaten Lampung Selatan. Jurnal 
Ilmiah Peternakan Terpadu, 3(4), 250255. https://doi.org/10.23960/jipt. v3i4.1107

Priyono, dan Priyanti, A. (2015). Penguatan Kelembagaan Koperasi Susu melalui Pendekatan Pengembangan Kawasan Peternakan Nasional. In Wartazoa (Vol. 25). Bogor.

Rahmah, U. I. L., and Somanjaya, R. (2019). The correlation between farmers characteristics and level of dairy management. Jurnal Ilmu Pertanian Dan Peternakan, 7(1), 102-107.

Resti, Y., Baars, R., Verschuur, M., and Duteurtre, G. (2017). The role of cooperative in the milk value chain in west bandung regency, West Java Province. Media Peternakan, 40(3), 210-217. https://doi.org/10.5398/ medpet.2017.40.3.210

Riska, P., Maruli, P., \& Firmansyah. (2021). Analisis Model Impor Susu di Indonesia Periode Tahun 2000 - 2016. Jurnal Agribis, 14(1), 6.

Riswara, A., Nurlina, L., dan Sulistyati, M. (2015). Peranan Koperasi Dalam Mendorong Pembangunan Kapasitas Peternak Sapi Perah Untuk Mencapai Skala Usaha Layak. Students E-Journal, 4(3), 1-12. Retrieved from http://journal. unpad.ac.id/ejournal/article / view/6899

Safitri, A. D. R., Susilowati, S., dan Dinasari, I. (2021). Peran Koperasi Penampungan Susu Dalam Peningkatan Ekonomi Peternak Sapi Perah Skala Rakyat. Jurnal Dinamika Rekasatwa, 4(1), 6369.

Simamora, T. (2020). Peningkatan Kompetensi Peternak dan Keberlanjutan Usaha Sapi Potong di Desa Oebkim Kecamatan Bikomi Selatan Kabupaten Timor Tengah Utara. Agrimor, 5(2), 20-23. https://doi. org/10.32938/ag.v5i2.1007
Soetriono, S., Hapsari, T. D., \& Muhlis, A. (2020). Pemodelan usaha ternak Kambing Senduro menuju penguatan kelembagaan korporasi di Kabupaten Lumajang. Livestock and Animal Research, 18(3), 229. https:// doi.org/10.20961/lar.v18i3.45993

Sternberg, R. J. (2012). The Assessment of Creativity: An Investment-Based Approach. Creativity Research Journal, 24(1), 3-12. https:// doi.org/10.1080 /10400419.2012.652925

Suciani, F., Sulistyati, M., dan Alim, S. (2015). Hubungan Antara Faktor Internal Dan Faktor Eksternal Dengan Tingkat Adopsi Teknologi Biogas Pada Peternak Sapi Perah. Student E-Journal Universitas Padjajaran, 4(2).

Sudaryanto, B., dan Hermawan, A. (2014). Prospek Pengembangan Sapi Perah Di Indonesia. Manajemen Dan Kinerja Pembangungan Pertanian, 261-281.

Sulastri, E., Haryadi, T., dan Inayah, E. (2019). Tingkat Kesadaran Ekologis Masyarakat Kampung Laut, Kabupaten Cilacap, Jawa Tengah. Jurnal Kawistara, 9(1), 78. https:// doi.org/10.22146/ kawistara.31484

Sulastri, E., and Maharjan, K. L. (2002). Role of Dairy Cooperative Services on Dairy Development in Indonesia : A Case Study of Daerah Istimewa Yogyakarta Province Article. Journal of International Development and Cooperation, 9(1), 17-39. https://doi. org/10.15027/14388

Susilowati, A., Hambali, I., dan Wahyuni, S. (2019). Kemandirian Peternak Sapi Perah dalam Upaya Pemberdayaan Masyarakat Pedesaan. Jurnal Pendidikan Nonformal, 14(2), 76. https://doi.org/10.17977/ um041v14i2p76-84

Usman, Y. (2010). Pengembangan Posdaya Sebagai Upaya Membangun Kemandirian Masyarakat dalam Rangka Mengatasi Kemiskinan : Studi Posdaya di Kelurahan Pasir Mulya, Kota Bogor, 
Jawa Barat. Sekolah Pascasarjana Yunasaf, U., Ginting, B., Slamet, M., dan UGM. Yogyakarta.

Van Fleet, D., Van Fleet, E., and Seperich, G. (2014). Agribusiness, Principles of Management. United States of America: Delmar.

Winarso, B. (2010). Prospek dan Kendala Pengembangan Agribisnis Ternak Kambing dan Domba di Indonesia. Bogor. Tjitropranoto, P. (2008). Peran Kelompok Peternak Dalam Mengembangkan Keberdayaan Peternak Sapi Perah (Kasus Di Kabupaten Bandung). Jurnal Penyuluhan, 4(2). https://doi.org/10.25015/ penyuluhan.v4i 2.2176 